Journal of Agrometeorology 23 (3) : 286-291 (September 2021)

\title{
Analysing water productivity response to sowing window, irrigation levels and mulching using CERES-wheat model
}

\author{
PARMINDER SINGH BUTTAR ${ }^{1}$, P. K. KINGRA ${ }^{1 *}$, R. K. PAL ${ }^{2}$, SOM PAL SINGH ${ }^{1}$ and \\ SAMANPREET KAUR ${ }^{3}$ \\ ${ }^{1}$ Dept of Climate Change and Agricultural Meteorology, PAU, Ludhiana, India \\ ${ }^{2}$ PAU-RRS, Bathinda, ${ }^{3}$ Dept of Soil and Water Engineering, PAU, Ludhiana, India \\ *Corresponding author: pkkingra@pau.edu
}

\begin{abstract}
Field experiments were carried out during rabi seasons of 2015-16 and 2016-17 at the Research Farm, Punjab Agricultural University, Ludhiana. Wheat variety PBW 621 was sown on three dates $\left(D_{1}: 4^{\text {th }}\right.$ week of October, $D_{2}: 2^{\text {nd }}$ week of November and $D_{3}: 4^{\text {th }}$ week of November) with two irrigation levels $\left(I_{1}:\right.$ IW/ $\mathrm{CPE}=0.9, \mathrm{I}_{2}$ : At CRI, 5-6 weeks after $1^{\text {st }}$ irrigation, 3-4/5-6 weeks after $2^{\text {nd }}$ irrigation, $2 / 4$ weeks after $3^{\text {rd }}$ irrigation as per dates of sowing) and mulch application ( $\mathrm{M}_{1}$ : without mulch, $\mathrm{M}_{2}$ : straw mulch @ $\left.5 \mathrm{t} \mathrm{ha}^{-1}\right)$. Earlier sown mulch applied crop with four post-sowing irrigations produced highest ( $\left.5312.5 \mathrm{~kg} \mathrm{ha}^{-1}\right)$ and late sown without mulch application crop with irrigation @IW/CPE $=0.9$ produced lowest grain yield $(3900.5 \mathrm{~kg}$ ha $^{-1}$ ). Simulation results depicted -1.1 to 16.8 per cent deviation in crop yield, -1.4 to -21.0 per cent in water use and 12.7 to 45.5 per cent in water productivity. Increase in temperature from $1^{\circ} \mathrm{C}$ to $3^{\circ} \mathrm{C}$ decreased wheat yield by 6.3 to 27.0 per cent under $D_{1}$ and 3.3 to 17.6 per cent under $D_{2}$, however, it increased from 8.1 to 16.2 per cent under $D_{3}$, indicating $D_{3}$ as most appropriate under future warming scenarios. Increase in $\mathrm{CO}_{2}$ concentration decreased water use and increased yield and water productivity.
\end{abstract}

Key words: Water productivity, CERES-wheat, temperature, $\mathrm{CO}_{2}$, irrigation levels, mulch

Wheat is an important cereal crop of India, ranking second after rice in area and production. India is second largest producer of wheat after China with about 12 per cent share in global food production. Area under wheat in Punjab was 35.12 lakh hectares with a production of 178.30 lac tonnes and productivity of 5.08 tha $^{-1}$ during 2017-18 (Anon., 2019). However, large yearto-year fluctuations are observed in its productivity due to significant inter- and intra-seasonal climatic variations in the region (Kingra, 2016, Kingra et al., 2017). The globally averaged combined land and ocean surface temperature data showed that the period from 1880 to 2012 was warmer by $0.85^{\circ} \mathrm{C}\left(0.65\right.$ to $\left.1.06^{\circ} \mathrm{C}\right)$ over the previous years (IPCC, 2014). The crop growth processes may be abruptly affected by increase in the frequency of extreme temperature along with the increase in the mean temperature (Wu et al., 2006).

The yield and evapotranspiration are affected by the combined effects of higher temperature, elevated $\mathrm{CO}_{2}$ concentration and change in precipitation (Walker and Schulze, 2008). There is a positive effect of increase in atmospheric $\mathrm{CO}_{2}$ on photosynthetic rates, which leads to increment in total biomass and yield of $\mathrm{C}_{3}$ crops (de Costa et al., 2006). There is a significant impact of all these changes on crop yield and water productivity especially in the tropical and sub-tropical regions, which can be managed by microclimatic modifications such as alteration in sowing time, mulch application and irrigation scheduling etc. Crop simulation models can help to find adequate adaptation strategies to avoid or reduce negative climate change effects on crop yield and exploit possible beneficial options (Iqbal et al., 2011).The DSSAT model has been widely used for many different applications (Hoogenboom et al., 2010) and hence used in the present study.

Water shortage is becoming severe in the western Indo-Gangetic Plains (IGP) because of the increasing competition faced by agriculture from the urban and also industrial sectors. As a result, water table is declining at an alarming rate due to which the pumping costs of 
farmers have increased. (Humphreys et al., 2010). Punjab is facing dual challenge of weather variability and overexploitation of its ground water resources with significant impact on crop productivity. Keeping this in view, the present study was conducted to simulate crop water requirement, grain yield and water productivity of wheat to variable temperature and $\mathrm{CO}_{2}$ levels under different dates of sowing, irrigation levels and mulch application.

\section{MATERIALS AND METHODS}

The present investigation was carried out at the Research Farm of Punjab Agricultural University, Ludhiana situated at latitude of $30^{\circ} 54>\mathrm{N}$, longitude of $75^{\circ} 54$, $\mathrm{E}$ and altitude of $247 \mathrm{~m}$ above the sea level. Wheat variety PBW 621 was sown on three dates $\left(D_{1}: 4^{\text {th }}\right.$ week of October, $\mathrm{D}_{2}: 2^{\text {nd }}$ week of November and $\mathrm{D}_{3}: 4^{\text {th }}$ week of November) with two irrigation levels $\left(\mathrm{I}_{1}: \mathrm{IW} / \mathrm{CPE}=0.9\right.$, $\mathrm{I}_{2}$ : Irrigation at CRI stage, 5-6 weeks after $1^{\text {st }}$ irrigation, $3-4 / 5-6$ weeks after $2^{\text {nd }}$ irrigation, $2 / 4$ weeks after $3^{\text {rd }}$ irrigation as per date of sowing) and mulch application ( $\mathrm{M}_{1}$ : without mulch, $\mathrm{M}_{2}$ : straw mulch @ $5 \mathrm{t} \mathrm{ha}^{-1}$ ). The experiment was laid out in a split plot design with dates of sowing in the main plots and irrigation and mulch application in combination as sub-plots. The soil of the experimental site was sandy loam. The soil properties used in the CERES-wheat model have been depicted in Table 1.

Crop yield under different treatments was recorded at the time of harvesting. Crop water use was recorded by periodic water depletion method and water productivity was computed from evapotranspiration and crop yield as mentioned below:

$\mathrm{WP}=\mathrm{Y} / \mathrm{ET}$

Where,

$\mathrm{WP}=$ Water productivity ( $\mathrm{kg} \mathrm{ha}^{-1} \mathrm{~mm}$ of water); $\mathrm{Y}=$ marketable yield $\left(\mathrm{kg} \mathrm{ha}^{-1}\right)$; ET $=$ Evapotranspiration (mm)

Crop yield, crop water requirements and water productivity were simulated using CERES-wheat model. The genetic coefficients used for wheat variety PBW-621 have been given in Table 2. Observed and simulated yield, water use and water productivity were then analysed statistically by computing standard deviation, correlation and root mean squared error. Sensitivity analysis was carried out to evaluate water productivity of wheat under variable temperatures $\left(+1^{\circ} \mathrm{C},+2^{\circ} \mathrm{C}\right.$ and $\left.+3^{\circ} \mathrm{C}\right)$ and $\mathrm{CO}_{2}$ levels (+200 ppm, $+400 \mathrm{ppm}$ and $+600 \mathrm{ppm}$ ) for different treatments.

\section{RESULTS AND DISCUSSION}

\section{Wheat yield}

The results revealed that early sown mulch applied crop with four post-sowing irrigations $\left(D_{1} I_{2} M_{2}\right)$ produced highest grain yield (5313 $\mathrm{kg} \mathrm{ha}^{-1}$ ) followed by (5096 kg ha-1) mid November sown mulch applied crop $\left(\mathrm{D}_{2} \mathrm{I}_{2} \mathrm{M}_{2}\right)$, whereas the lowest yield (3901 kg ha-1) was observed in the late sown without mulch application crop with irrigation @IW/CPE $=0.9\left(\mathrm{D}_{3} \mathrm{I}_{1} \mathrm{M}_{1}\right)$ (Table 3 ). The simulation analysis also depicted highest yield (5257 kg ha-1) under earlier sown mulch applied crop with four recommended post-sowing irrigations $\left(D_{1} \mathrm{I}_{2} \mathrm{M}_{2}\right)$ followed by (5186 $\mathrm{kg} \mathrm{ha}^{-1}$ ) under mid November sown mulch applied crop $\left(\mathrm{D}_{2} \mathrm{I}_{2} \mathrm{M}_{2}\right)$. Although less crop yield was observed under late sown conditions, but simulation analysis depicted the scope of improvement in wheat yield (5091 kg ha-1) with irrigation management and mulch application $\left(\mathrm{D}_{3} \mathrm{I}_{2} \mathrm{M}_{2}\right)$. Simulation results depicted deviation in crop yield in the range of -1.1 to 16.8 per cent in different treatments.

\section{Crop water use}

Among different treatments, crop water depletion was observed to be highest ( $408 \mathrm{~mm}$ ) under earlier sown without mulch applied crop with four recommended post-sowing irrigations $\left(\mathrm{D}_{1} \mathrm{I}_{2} \mathrm{M}_{1}\right)$ (Table 3 ) as compared with rest of the treatments. In general, water depletion decreased with delay in sowing, which might be due to reduction in crop duration under late sown conditions. However, irrigation management and mulch application seemed to be quite effective in checking water depletion under all the dates of sowing. Simulation analysis also depicted highest crop water use (362 mm) under earlier sown without mulch crop with four recommended postsowing irrigations $\left(\mathrm{D}_{1} \mathrm{I}_{2} \mathrm{M}_{1}\right)$ and lowest $(290 \mathrm{~mm})$ under late November sown mulch applied crop with four post-sowing irrigations $\left(\mathrm{D}_{3} \mathrm{I}_{2} \mathrm{M}_{2}\right)$. Simulation analysis under-estimated crop water use in all the treatments, the deviation ranging from -1.4 to -21.0 per cent.

\section{Water productivity}

Late October and mid November sown mulch 
Table 1: Soil properties used for CERES-wheat model

\begin{tabular}{|c|c|c|c|c|c|c|c|c|c|c|}
\hline @ SCOM & SALB & SLU1 & SLDR & SLRO & SLNF & SLPF & SMHB & SMPX & \multicolumn{2}{|c|}{ SMKE } \\
\hline-99 & 0.13 & 6 & 0.4 & 73 & 1 & 1 & IB001 & IB001 & \multicolumn{2}{|l|}{ IB001 } \\
\hline (a) SLB & SLLL & SDUL & SSAT & SRGF & SSKS & SBDM & SLOC & SLCL & SLSI & SLHW \\
\hline 15 & 0.13 & 0.236 & 0.343 & 1 & 1 & 1.74 & 0.41 & 29 & 10 & 6.9 \\
\hline 30 & 0.115 & 0.251 & 0.321 & 0.638 & 1 & 1.8 & 0.33 & 29 & 6 & 7.1 \\
\hline 45 & 0.109 & 0.231 & 0.347 & 0.472 & 1 & 1.73 & 0.22 & 30 & 4 & 6.6 \\
\hline 60 & 0.101 & 0.226 & 0.385 & 0.35 & 1 & 1.63 & 0.21 & 28 & 7 & 6.9 \\
\hline 105 & 0.099 & 0.222 & 0.354 & 0.142 & 1 & 1.71 & 0.19 & 28 & 6 & 7.1 \\
\hline 120 & 0.104 & 0.196 & 0.343 & 0.105 & 1 & 1.74 & 0.17 & 26 & 6 & 7.1 \\
\hline \multicolumn{5}{|c|}{ SCOM: Colour, moist, munsell hue } & \multicolumn{6}{|c|}{ SLB: Depth, base of layer, cm } \\
\hline \multicolumn{5}{|c|}{ SALB: Albedo, fraction } & \multicolumn{6}{|c|}{ SLLL: Lower limit $\mathrm{cm}^{3} \mathrm{~cm}^{-3}$} \\
\hline \multicolumn{5}{|c|}{ SLPF: Photosynthesis factor, 0 to 1 scale } & \multicolumn{6}{|c|}{ SBDM: Bulk density, $\mathrm{g} \mathrm{cm}^{-3}$} \\
\hline \multicolumn{5}{|c|}{ SMHB: $\mathrm{pH}$ in buffer determination method, code } & \multicolumn{6}{|c|}{ SLOC: Organic carbon, \% } \\
\hline \multicolumn{5}{|c|}{ SMPX: Phosphorus determination code } & \multicolumn{6}{|c|}{ SLCL: Clay $(<0.002 \mathrm{~mm}), \%$} \\
\hline \multicolumn{5}{|c|}{ SMKE: Potassium determination method, code } & \multicolumn{6}{|c|}{ SLSI: Silt (0.05 to $0.002 \mathrm{~mm}), \%$} \\
\hline \multicolumn{5}{|c|}{-99: Not available } & \multicolumn{6}{|c|}{ SLHW: pH in water } \\
\hline
\end{tabular}
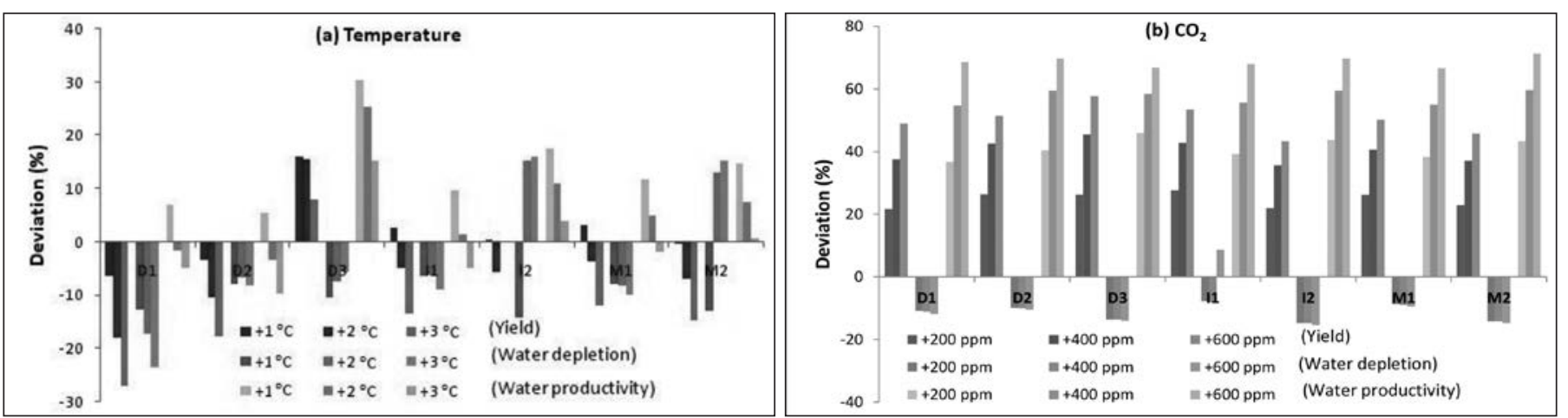

Fig. 1: Effect of increase in air temperature and $\mathrm{CO}_{2}$ concentration on yield, water depletion and water productivity of wheat under different dates of sowing, irrigation levels and mulch application

applied crop with four post-sowing irrigations $\left(\mathrm{D}_{2} \mathrm{I}_{2} \mathrm{M}_{2}\right.$ and $\mathrm{D}_{1} \mathrm{I}_{2} \mathrm{M}_{2}$ ) reported highest water productivity (13.5 and $13.4 \mathrm{~kg} \mathrm{ha}^{-1} \mathrm{~mm}^{-1}$, respectively) followed by earlier sown mulch applied crop (13.0 $\left.\mathrm{kg} \mathrm{ha}^{-1} \mathrm{~mm}^{-1}\right)$ with irrigation application@ @IW/CPE = $0.9\left(\mathrm{D}_{1} \mathrm{I}_{1} \mathrm{M}_{2}\right)$. Among all the dates of sowing and irrigation levels, mulch application improved crop water productivity. Simulation analysis also depicted highest water productivity (17.6 and 16.7 $\mathrm{kg} \mathrm{ha}^{-1} \mathrm{~mm}^{-1}$ ) under late and mid November sown mulch applied crop with four post-sowing irrigations $\left(\mathrm{D}_{3} \mathrm{I}_{2} \mathrm{M}_{2}\right.$ and $\mathrm{D}_{2} \mathrm{I}_{2} \mathrm{M}_{2}$, respectively). Over-estimation of simulated water productivity was observed, the deviation being in the range of 12.8 - 45.0 per cent under different treatments. However, the deviation ranged from 14.5 - 16.2 per cent for late October sown crop, 12.7 - 23.7 per cent for mid November and 25.5 - 45.5 per cent for end November sown crop, depicting ample scope of improvements in wheat productivity with microclimatic modifications especially under late sown conditions (Table 3).

\section{Relation between observed and simulated parameters}

A good correlation was found in observed and simulated yield. Average wheat yield of $4552.4+390.3$ and $4718.3 \pm 445.8 \mathrm{~kg} \mathrm{ha}^{-1}$ was observed during 2015-16 and 2016-17 seasons, respectively, whereas simulated yield for the corresponding years was 4721.9+237.8 and $5185.0 \pm 246.7 \mathrm{~kg} \mathrm{ha}^{-1}$, respectively with correlation coefficient of 0.84 and 0.81 and RMSE of 277.9 and 540.0 
Table 2: Genetic coefficients of wheat

\begin{tabular}{lll}
\hline Genetic coefficient & \multicolumn{1}{c}{ Definition } & Value \\
\hline P1V & Days,optimum vernalizing temperature,required for vernalization & 20 \\
P1D & Photoperiod response (\% reduction in rate/10 h drop in pp) & 65 \\
P5 & Grain filling (excluding lag) phase duration $\left({ }^{\circ} \mathrm{C} . \mathrm{d}\right)$ & 780 \\
G1 & Kernel number per unit canopy weight at anthesis (\#/g) & 20 \\
G2 & Standard kernel size under optimum conditions (mg) & 42 \\
G3 & Standard,non-stressed mature tiller wt (incl grain) (g dwt) & 2.4 \\
PHINT & Interval between successive leaf tip appearances $\left({ }^{\circ} \mathrm{C} . d\right)$ & 90 \\
\hline
\end{tabular}

Table 3: Actual and predicted yield, evapotranspiration and water productivity of wheat under different dates of sowing, irrigation levels and mulch application

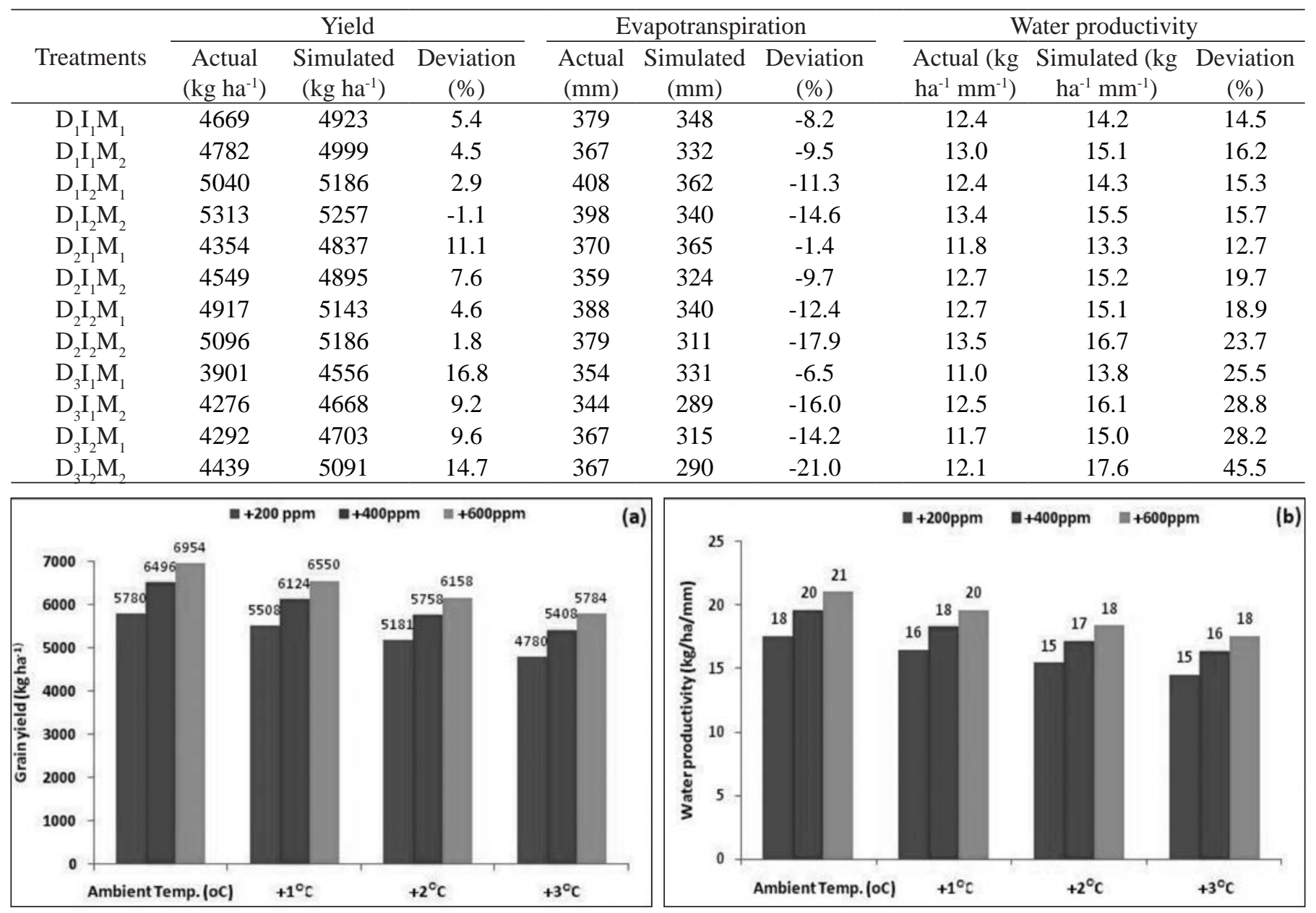

Fig. 2: Interaction effect of temperature and $\mathrm{CO}_{2}$ on (a) yield and (b) water productivity of wheat

$\mathrm{kg} \mathrm{ha}^{-1}$, respectively (Table 4). However, pooled analysis depicted average observed and simulated productivity of $4635.4+418.5$ and $4953+334.8 \mathrm{~kg} \mathrm{ha}^{-1}$ with correlation coefficient of 0.71 and RMSE of $429.4 \mathrm{~kg} \mathrm{ha}^{-1}$. Similarly, average observed and simulated crop water use was found to be $367.5 \pm 21.2$ and $327.0 \pm 22.1 \mathrm{~mm}$, respectively during 2015-16 and 379.2 \pm 16.3 and $330.7 \pm 29.0 \mathrm{~mm}$ during 2016-17 with correlation coefficient of 0.59 and 0.47 and RMSE of 44.6 and $54.4 \mathrm{~mm}$ during both the years. However, pooled analysis indicated observed ET of $373.3 \pm 19.4 \mathrm{~mm}$ and simulated ET of $328.9 \pm 25.3 \mathrm{~m}$ with correlation coefficient of 0.51 and RMSE of 49.7 $\mathrm{mm}$. Average water productivity of wheat was observed to be $12.4 \mathrm{~kg} \mathrm{ha}^{-1} \mathrm{~mm}^{-1}$ during both the years as well as in polled analysis, whereas simulated water productivity was $14.5 \pm 1.1 \mathrm{~kg} \mathrm{ha}^{-1} \mathrm{~mm}^{-1}$ during $2015-16,15.8 \pm 1.5 \mathrm{~kg}$ ha $^{-1} \mathrm{~mm}^{-1}$ during 2016-17 and 15.1 $\pm 1.4 \mathrm{~kg} \mathrm{ha}^{-1} \mathrm{~mm}^{-1}$ in the pooled analysis with correlation coefficients of 0.52 , 
Table 4: Statistical analysis of observed and predicted yield, evapotranspiration and water productivity of wheat

\begin{tabular}{ccccc}
\hline Period / Parameter & Actual & Simulated & Correlation coefficient & RMSE \\
\hline Yield (kg ha ${ }^{-1}$ ) & & & & \\
$2015-16$ & $4552.4 \pm 390.3$ & $4721.9 \pm 237.8$ & $0.84^{* *}$ & 277.9 \\
$2016-17$ & $4718.3 \pm 445.8$ & $5185.0 \pm 246.7$ & $0.81^{* *}$ & 540.0 \\
Pooled & $4635.4 \pm 418.5$ & $4953.5 \pm 334.8$ & $0.71^{* *}$ & 429.4 \\
\hline Evapotranspiration (mm) & & & & \\
$2015-16$ & $367.5 \pm 21.1$ & $327.0 \pm 22.1$ & $0.59^{*}$ & 44.6 \\
$2016-17$ & $379.2 \pm 16.3$ & $330.7 \pm 29.0$ & 0.47 & 54.4 \\
Pooled & $373.3 \pm 19.4$ & $328.9 \pm 25.3$ & 0.51 & 49.7 \\
\hline Water productivity (kg ha-1 $\left.\mathbf{~ m m}^{-1}\right)$ & & & 2.3 \\
2015-16 & $12.4 \pm 0.6$ & $14.5 \pm 1.1$ & 0.52 & 3.6 \\
2016-17 & $12.4 \pm 0.9$ & $15.8 \pm 1.5$ & 0.34 & 3.0 \\
Pooled & $12.4 \pm 0.8$ & $15.1 \pm 1.4$ & 0.37 & \\
\hline
\end{tabular}

Significant at $5(*)$ and $1\left({ }^{* *}\right)$ percent Probability level

0.34 and 0.37 and RMSE of 2.3, 3.6 and $3.0 \mathrm{~kg} \mathrm{ha}^{-1} \mathrm{~mm}^{-1}$ during the corresponding periods.

\section{Effect of increased temperature}

Increase in temperature from $1^{\circ} \mathrm{C}$ to $3^{\circ} \mathrm{C}$ decreased wheat yield by -6.3 to -27.0 per cent under $\mathrm{D}_{1}$ and -3.3 to -17.6 per cent under $\mathrm{D}_{2}$, however, increase in yield from 8.1 to 16.2 per cent was observed under $\mathrm{D}_{3}$, which indicates that sowing of wheat during $4^{\text {th }}$ week of November is most appropriate sowing window under future warming scenarios (Fig. 1a). Similarly, increase in temperature resulted in reduced grain yield under irrigation and mulch treatments. Simulation results also depicted decrease in water uptake by the crop with increase in temperature under all the dates of sowing, which might be due to enhanced maturity under warming scenarios. $\mathrm{I}_{2}$ irrigation regime and mulch application resulted in reduced water depletion, thus improving crop water productivity. The simulation analysis also revealed that under $I_{1}$ and $M_{1}$ treatments crop water productivity decreased beyond $2^{\circ} \mathrm{C}$ increase in temperature, however, with irrigation management $\left(\mathrm{I}_{2}\right)$ and mulch application $\left(\mathrm{M}_{2}\right)$, the crop water productivity could be managed even upto $3^{\circ} \mathrm{C}$ increase in temperature.

A critical appraisal of simulation analyses clearly depicted the effect of sowing time, irrigation and mulching in sustaining wheat productivity under warming scenarios. The analysis indicated that with increase in temperature by $3^{\circ} \mathrm{C}$, the wheat yield could be improved from $3614 \mathrm{~kg} \mathrm{ha}^{-1}$ to $4568 \mathrm{~kg} \mathrm{ha}^{-1}$ by shifting sowing time from $4^{\text {th }}$ week of October to $4^{\text {th }}$ week of
November as crop water requirement decreases and water productivity increases. As in the $4^{\text {th }}$ November sown crop, water depletion decreased by 5-10 per cent and water productivity improved by $15-30$ per cent with increase in temperature by 1 to $3^{\circ} \mathrm{C}$ (Fig.1a).

\section{Effect of increased $\mathrm{CO}_{2}$ concentration}

Increase in $\mathrm{CO}_{2}$ concentration from 200 to 600 ppm increased grain yield under all the treatments, in the range of 21.7 to $49.0 \%, 26.4$ to 51.5 per cent and 26.3 to 57.7 per cent under $\mathrm{D}_{1}, \mathrm{D}_{2}$ and $\mathrm{D}_{3}$, respectively. Among the irrigation levels, increase in yield was 27.7 to 53.4 per cent and 22.0 to 43.4 per cent under $I_{1}$ and $I_{2}$, respectively and under mulch treatment, it was improved to the tune of 26.2 to 50.3 per cent without mulch application and 22.9 to 45.8 per cent under mulch (Fig. 1b). Simulation results also depicted decrease in water depletion and increase in water productivity with increase in $\mathrm{CO}_{2}$ concentration in all the treatments. Among the dates of sowing, the crop sown in fourth week of November depicted highest decrease in water depletion ranging from 13.7 to 14.0 per cent. Similarly, irrigation management and mulch application significantly reduced water depletion and improved water productivity. $\mathrm{I}_{2}$ irrigation level decreased water depletion by 14.8 to 15.4 per cent and improved water productivity by 43.7 to 69.8 per cent. Similarly, mulch application reduced water depletion by 14.2 to 14.8 per cent and improved water productivity by 43.4 to 71.3 per cent with increased $\mathrm{CO}_{2}$ concentration from 200 to $600 \mathrm{ppm}$. Among all the treatments, mulch application depicted maximum water productivity $\left(22.1 \mathrm{~kg} \mathrm{ha}^{-1} \mathrm{~mm}^{-1}\right)$ with increased $\mathrm{CO}_{2}$ concentration upto $600 \mathrm{ppm}$. 


\section{Interaction effect of increased temperature and $\mathrm{CO}_{2}$}

Analysis of interactive effect of temperature and $\mathrm{CO}_{2}$ had revealed that reduction in yield and water productivity due to increase in temperature could be negated by the positive effect of increase in $\mathrm{CO}_{2}$ concentration. Almost comparable grain yield was observed at ambient temperature with increase in $\mathrm{CO}_{2}$ by $200 \mathrm{ppm}\left(5780 \mathrm{~kg} \mathrm{ha}^{-1}\right)$, with $2^{\circ} \mathrm{C}$ increase in temperature and $\mathrm{CO}_{2}$ concentration increment by $400 \mathrm{ppm}(5758 \mathrm{~kg}$ $\left.\mathrm{ha}^{-1}\right)$ and $3^{\circ} \mathrm{C}$ increase in temperature with increase in $\mathrm{CO}_{2}$ by $600 \mathrm{ppm}$ ( $5784 \mathrm{~kg} \mathrm{ha}^{-1}$ ) (Fig. 2a\&b). Similar effect was observed for water productivity at ambient temperature with $200 \mathrm{ppm}$ increase in $\mathrm{CO}_{2}$ concentration, $1^{\circ} \mathrm{C}$ increase in temperature with $\mathrm{CO}_{2}$ increment by $400 \mathrm{ppm}$ and $2-3^{\circ} \mathrm{C}$ increase in temperature with $\mathrm{CO}_{2}$ concentration increment of $600 \mathrm{ppm}$ (18 kg ha-1 $\mathrm{mm}^{-1}$ each). These results indicate that increase in $\mathrm{CO}_{2}$ concentration by $600 \mathrm{ppm}$ can counter balance the negative effect of global warming scenarios by $2-3^{\circ} \mathrm{C}$ on wheat grain yield and water productivity.

\section{CONCLUSION}

The study concluded that adoption of appropriate sowing time, irrigation management and mulch application have a significant effect on sustaining crop yield and water productivity even under late sown conditions in wheat. Simulation analysis indicated sowing of wheat during fourth week of November to be most appropriate in view of future global warming scenarios. Sensitivity analysis indicated that increase in $\mathrm{CO}_{2}$ concentration by $600 \mathrm{ppm}$ can counterbalance the negative effect of global warming scenarios by $2-3^{\circ} \mathrm{C}$ on wheat grain yield and water productivity in the region.

Conflict of Interest Statement : The author(s)declare(s) that there is no conflict of interest.

Disclaimer : The contents, opinions, and views expressed in the research article published in the Journal of Agrometeorology are the views of the authors and do not necessarily reflect the views of the organizations they belong to.

Publisher's Note : The periodical remains neutral with regard to jurisdictional claims in published maps and institutional affiliations.

\section{REFERENCES}

Annonymous. (2019). Package and Practices for Crops of Punjab - Rabi 2019. Punjab Agricultural University, Ludhiana. de Costa, W.A.J.M., Weerakoon, W.M.W., Herath, H.M.L.K., Amaratunga, K.S.P.,Abeywardena, R.M.I. (2006). Physiology of yield determination of rice under elevated carbon dioxide at high temperatures in a subhumid tropical climate. Field Crops Res., 96: 336-347.

Hoogenboom, G., Jones, J.W., Porter, C.H., Wilkens, P.W., Boote, K.J.,Hunt, L.A. and Tsuji, G.Y/ (eds) (2010). Decision support system for agrotechnology transfer version 4.5. Volume 1: overview. University of Hawaii, Honolulu.

Humphreys, E., Kukal, S.S., Christen, E.W., Hira, G.S., Balwinder-Singh, Sudhir-Yadav and Sharma, R.K. (2010). Halting the groundwater decline in north west India - which crop technologies will be winners? Adv. Agron., 109: 155-217.

IPCC. (2014). Climate change impacts, adaptation and vulnerability. Working group II contribution to the fifth assessment report of the intergovernmental panel on climate change. Technical report. Cambridge University Press, Cambridge, UK/ NewYork, USA.

Iqbal, M. A., Eitzinger, J., Formayer, H., Hassan, A. and Heng, L. K. (2011). A simulation study for assessing yield optimization and potential for water reduction for summer-sown maize under different climate change scenarios. J.Agric. Sci., Cambridge 149: 129-143.

Kingra, P.K. (2016). Climate variability impacts on wheat productivity in central Punjab. J. Agrometeorol., 18(10):97-99.

Kingra P.K., Setia Raj, Singh Simranjeet, Kaur Jatinder, Kaur Satinder, Singh Som Pal, Kukal, S. S. and Pateriya, Brijendra. (2017). Climatic variability and its characterisation over Punjab, India. $J$. Agrometeorol., 19 (3): 246-50.

Walker, N.J. and Schulze, R.E. (2008). Climate change impacts on agro-ecosystem sustainability across three climate regions in the maize belt of South Africa. Agric. Ecosyst. Environ., 124: 114-124.

Wu, D.R., Yu, Q., Lua, C.H. and Hengsdijk, H. (2006). Quantifying production potentials of winter wheat in the North China Plain. European $J$. Agron., 24: 226-235. 